\title{
Selection of Microstrip Patch Antenna Substrate for WLAN Application Using Multiple Attribute Decision Making Approach
}

\author{
Navneet Gupta and Rituraj Raman \\ Department of Electrical and Electronics Engineering, Birla Institute of Technology and Science, Pilani, Rajasthan 333031, India \\ Correspondence should be addressed to Navneet Gupta; dr.guptanavneet@gmail.com
}

Received 30 June 2014; Accepted 7 October 2014; Published 22 October 2014

Academic Editor: Giancarlo Bartolucci

Copyright ( 2014 N. Gupta and R. Raman. This is an open access article distributed under the Creative Commons Attribution License, which permits unrestricted use, distribution, and reproduction in any medium, provided the original work is properly cited.

\begin{abstract}
This paper presents a material selection approach for selecting microstrip patch antenna substrate for WLAN applications using multiple attribute decision making (MADM) approach. In this paper, different microwave dielectric materials for substrate and their properties like relative permittivity, quality factor, and temperature coefficient of the resonant frequency are taken into consideration and MADM approach is applied to select the best material for microstrip patch antenna. It is observed that $\mathrm{Pb}_{0.6} \mathrm{Ca}_{0.4} \mathrm{ZrO}_{3}$ is the best material for the antenna substrate in MPA for WLAN applications. It was observed that the proposed result is in accordance with the experimental finding thus justifying the validity of the proposed study.
\end{abstract}

\section{Introduction}

Due to increase in variety of mobile communication equipment, such as laptops, personal digital assistants, smartphones, and wireless modems, the demand for adaptable and functional miniature antennas are growing very fast [1]. A wireless local area network (WLAN) links two or more devices using some wireless distribution method (typically spread-spectrum or OFDM radio) and usually providing a connection through an access point to the wider internet. This gives users the mobility to move around within a local coverage area and still be connected to the network [2, 3]. To achieve this, microstrip patch antennas (MPAs) play an important role and are good candidates for wide-band applications.

Material selection for MPA in general and dielectric materials for its substrate in particular are complicated as there are a number of materials that have been proposed; however, each of these materials has certain merits and limitations. The key performance indices for MPA substrate are relative permittivity, quality factor, and temperature coefficient of the resonant frequency. This paper discusses a strategy for selecting suitable material for substrate based on multiple attribute decision making (MADM) approach [4] in order to improve the antenna performance.
This paper is organized as follows. Section 2 explains the microstrip patch antenna design. Section 3 explains the selection criteria of materials. This section describes the decision making approach and details of technique for order preference by similarity to ideal solution (TOPSIS), while Section 4 includes the application of TOPSIS method to antenna substrate material selection in MPAs. Section 5 presents the conclusions drawn from this study.

\section{Microstrip Patch Antenna Design}

Schematic view of microstrip patch antenna (MPA) is shown in Figure 1. The patch and the ground plane are separated by a dielectric substrate. For WLAN application the size of antenna should be small. In order to reduce the size of the antenna, substrate with high dielectric constants must be used. However, this may cause the increase in the cost of material and the frequency shift due to the material tolerance and result in narrowing of the operating bandwidth. So, the design of the antenna patch also plays an important role.

Dielectric substrate materials used in patch antennas include ceramic, semiconductor, ferromagnetic, synthetic, composite, and foams. The properties of substrate materials commonly studied while designing the patch antennas are 


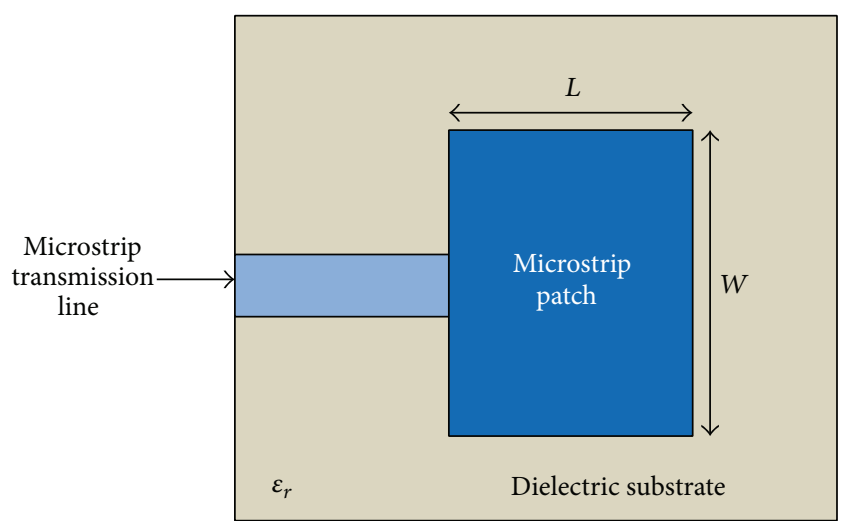

FIGURE 1: The basic structure of microstrip patch antenna (MPA).

permittivity $\left(\varepsilon_{r}\right)$, quality factor (Q-factor), and temperature coefficient of the resonant frequency $\left(\tau_{f}\right)$.

Certain other properties sintering temperature, thermal properties, and chemical compatibility are also considered while dealing with the fabrication aspects.

For antenna in WLAN routers the desirable properties are low permittivity, high quality factor, low temperature coefficient of resonance, and low cost. This is because low permittivity allows larger bandwidth and a high quality factor provides better selectivity and is also responsible for strong resonance and high frequency stability. The variation of resonant frequency with temperature is undesirable, so the absolute value of this parameter should be as low as possible. If we are going for mass production of such antennas then cost should be as low as possible.

\section{Multiple Attribute Decision Making Approach}

MCDM (multiple criteria decision making) methods can be used to solve uncertainty problems. Multiple criteria decision making (MCDM) can be broadly divided into

(i) multiobjective decision making (MODM);

(ii) multiattribute decision making (MADM).

MODM is optimization of an alternative or alternatives on the bases of prioritized objectives.

MADM is selection of an alternative from a set of alternatives based on prioritized attributes of the alternatives.

MODM studies decision problems in which the decision space is continuous and design alternatives are defined implicitly by a mathematical programming structure (a typical example is mathematical programming problems with multiple objective functions).

On the other hand, MADM concentrates on problems with discrete decision spaces and alternatives are defined explicitly by a finite list of attributes. In these problems the set of decision alternatives has been predetermined. Moreover, an attribute with a direction may be an objective. Different types of methods are developed based on MADM approach. For the present work, we adopted the TOPSIS method to find the best alternative [4]. TOPSIS stands for technique for order preference by similarity to ideal solution. This is based on the idea that the chosen alternative should be nearer to the ideal solution and away from the negative-ideal solution in some geometrical sense.

The TOPSIS method takes the following steps.

Step 1 (construct the normalized decision matrix). The value of each criterion is normalized to 1 . The characteristics $Q \times$ $f(\mathrm{GHz}) \varepsilon_{r}, \tau_{f}\left(\mathrm{ppm} /{ }^{\circ} \mathrm{C}\right)$, and base material cost $(\$ / \mathrm{g})$ are considered for criterion with higher benefits in higher value; each value is divided by the highest value. For criterion with higher benefits in lower value, each value is divided by the highest value, giving the highest value a value of 1 , and then these values are subtracted from 1 . So we get the normalized decision matrix $R$.

Step 2 (construct the weighted normalized decision matrix). With the set of weights $W=\left(w_{1}, w_{2}, w_{3}, \ldots, w_{n}\right)$ the weighted normalized matrix $V$ can be generated as follows:

$$
V=R W=\left[\begin{array}{cccc}
w_{1} \cdot r_{11} & w_{2} \cdot r_{12} & \cdots & w_{n} \cdot r_{1 n} \\
w_{1} \cdot r_{21} & w_{2} \cdot r_{22} & \cdots & w_{n} \cdot r_{2 n} \\
\cdot & \cdot & \cdots & \cdot \\
\cdot & \cdot & \cdots & \cdot \\
w_{1} \cdot r_{m 1} & w_{2} \cdot r_{m 2} & \cdots & w_{n} \cdot r_{m n}
\end{array}\right]
$$

where " $m$ " is the number of alternatives and " $n$ " is the number of criteria.

Step 3 (determine the ideal and negative-ideal solutions). The ideal solution $A^{*}$ and the negative-ideal solution, denoted by $A^{-}$, are

$$
\begin{aligned}
A^{*}= & \left\{\left(\max v_{i j} \mid j \in J_{1}\right),\left(\max v_{i j} \mid j \in J_{2}\right),\right. \\
& i=1,2,3, \ldots, m\} \\
= & \left\{v_{1}^{*}, v_{2}^{*}, \ldots, v_{n}^{*}\right\} \\
A^{-}= & \left\{\left(\min v_{i j} \mid j \in J_{1}\right),\left(\min v_{i j} \mid j \in J_{2}\right),\right. \\
& i=1,2,3, \ldots, m\} \\
= & \left\{v_{1}^{-}, v_{2}{ }^{-}, \ldots, v_{n}{ }^{-}\right\} .
\end{aligned}
$$

In (2), $J_{1}=\{j=1,2,3, \ldots, n$ and $j$ is associated with benefit criteria $\}, J_{2}=\{j=1,2,3, \ldots, n$ and $j$ is associated with cost criteria\}.

Therefore, it is obvious that the previous created alternatives $A^{*}$ and $A^{-}$represent the most preferable alternative, that is, the ideal solution, and the least preferable alternative or the negative-ideal solution, respectively.

Step 4 (calculate the separation measure). Next the separation distances of each alternative from the ideal solution and the negative-ideal solution are reached by the $n$-dimensional Euclidean distance method. That means $S_{i}^{*}$ is the distance 
TABLE 1: Characteristics parameters of selected materials [5-13].

\begin{tabular}{lccccc}
\hline S. number & \multicolumn{1}{c}{ Substrate material } & $\varepsilon_{r}$ & $\mathrm{Q} \times f(\mathrm{GHz})$ & $\tau_{f}\left(\mathrm{ppm} /{ }^{\circ} \mathrm{C}\right)$ & Base material cost $(\$ / \mathrm{g})$ \\
\hline $\mathrm{A}$ & $0.9\left(\mathrm{Zr}_{0.8} \mathrm{Sn}_{0.2}\right) \mathrm{TiO}_{4}+0.1 \mathrm{MgCO}_{3}$ & 38.9 & 4000 & -2.3 & 6.32 \\
$\mathrm{~B}$ & $\mathrm{La}_{0.4} \mathrm{Ba}_{0.6} \mathrm{Ti}_{0.6} \mathrm{Yb}_{0.4} \mathrm{O}_{3}$ & 65 & 4500 & 1 & 0.148 \\
$\mathrm{C}$ & $0.58 \mathrm{ZnNb}_{2} \mathrm{O}_{6}-0.42 \mathrm{TiO}_{2}$ & 45 & 6000 & 0 & 0.132 \\
$\mathrm{D}$ & $\mathrm{Ca}_{0.4}\left(\mathrm{~L}_{1 / 2} \mathrm{Nd}_{1 / 2}\right)_{0.6} \mathrm{TiO}_{3}$ & 113 & 5000 & 8 & 0.172 \\
$\mathrm{E}$ & $\mathrm{Pb}_{0.6} \mathrm{Ca}_{0.4} \mathrm{ZrO}_{3}$ & 94 & 3600 & -10 & 0.16 \\
$\mathrm{~F}$ & $\mathrm{BaO} \mathrm{PbO}_{-} \mathrm{Nd}_{2} \mathrm{O}_{5}-\mathrm{TiO}_{2}$ & 88 & 5000 & 0 & 0.148 \\
$\mathrm{G}$ & $\mathrm{Pb}_{0.45} \mathrm{Ca}_{0.55}\left(\mathrm{Fe}_{1 / 2} \mathrm{Nb}_{1 / 2}\right) \mathrm{O}_{3}$ & 93 & 6000 & 2 & 0.144 \\
$\mathrm{H}$ & $\mathrm{Ba}_{4.2}\left(\mathrm{Sm}_{0.8} \mathrm{Nd}_{0.2}\right)_{9.2} \mathrm{Ti}_{18} \mathrm{O}_{54}$ & 84 & 9000 & 0 & 0.132 \\
$\mathrm{I}$ & $\left(\mathrm{Ba}_{0.8} \mathrm{Sr}_{0.2}\right)_{4.2} \mathrm{Sm}_{9.2} \mathrm{Ti}_{18} \mathrm{O}_{54}$ & 82.3 & 2860 & 0.4 & 0.132 \\
$\mathrm{~J}$ & $\left(\mathrm{Ba}_{0.95} \mathrm{Ca}_{0.05}\right) \mathrm{O}-\mathrm{Sm}_{2} \mathrm{O}_{3}-4.5 \mathrm{TiO}_{2}$ & 81 & 9500 & 2 & 0.132 \\
\hline
\end{tabular}

(in an Euclidean sense) of each alternative from the ideal solution and is defined as

$$
S_{i}^{*}=\sqrt{\sum_{j=1}^{n}\left(v_{i j}-v_{j}^{*}\right)^{2}} \text { for } i=1,2,3, \ldots, m
$$

and the distance from the negative-ideal solution is defined as follows:

$$
S_{i}^{-}=\sqrt{\sum_{j=1}^{n}\left(v_{i j}-v_{j}^{-}\right)^{2}} \text { for } i=1,2,3, \ldots, m .
$$

Here, $v_{j}^{*}$ and $v_{j}{ }^{-}$are the values of the best and the worst alternative in a particular criteria " $j$."

Step 5 (calculate the relative closeness to the ideal solution). The relative closeness of an alternative $A_{i}$ with respect to the ideal solution $A^{*}$ is represented by

$$
C_{i}=\frac{S_{i}^{*}}{S_{i}^{*}+S_{i}^{-}},
$$

where $0<C_{i}^{*}<1$ and $i=1,2,3, \ldots, m$.

Apparently an alternative $A_{i}$ is closer to the ideal solution as $C_{i}^{*}$ approaches 1.

Thus, $C_{i}^{*}=1$, if $A_{i}=A^{*}$, and $C_{i}^{-}=0$, if $A_{i}=A^{-}$.

Step 6 (rank the preference order). Now a preference order can be ranked according to the order of $C_{i}^{*}$. Therefore, the best alternative is the one nearer to the ideal solution and away from the negative-ideal solution.

The labels proposed for the weighting are the following: $W=\{$ Essential, Very High, Fairly High, High, Moderate,

Low, Fairly Low, Very Low, Unnecessary\} .

\section{Result and Discussion}

Various properties of different possible materials for patch antenna substrate suitable for WLAN applications are tabulated and shown in Table 1.
The normalized matrix $R$ is

$$
R=\left[\begin{array}{cccc}
0.66 & 0.42 & 0.77 & 0 \\
0.42 & 0.47 & 0.9 & 0.976582 \\
0.6 & 0.63 & 1 & 0.979114 \\
0 & 0.53 & 0.2 & 0.972785 \\
0.17 & 0.38 & 0 & 0.974684 \\
0.22 & 0.53 & 1 & 0.976582 \\
0.18 & 0.63 & 0.8 & 0.977215 \\
0.26 & 0.95 & 1 & 0.979114 \\
0.27 & 0.3 & 0.96 & 0.979114 \\
0.28 & 1 & 0.8 & 0.979114
\end{array}\right] .
$$

Highest value of weight is given to that parameter which is more essential, in this case it is $\varepsilon_{r}$ and least value is given to the parameter which is not that much important. Hence the weighted matrix $W$ is

$$
W=\left[\begin{array}{llll}
0.4 & 0.3 & 0.2 & 0.1
\end{array}\right]
$$

The weighted normalized matrix $V$ is

$$
V=\left[\begin{array}{cccc}
0.264 & 0.126 & 0.154 & 0 \\
0.168 & 0.141 & 0.18 & 0.097658 \\
0.24 & 0.189 & 0.2 & 0.097911 \\
0 & 0.159 & 0.04 & 0.097278 \\
0.068 & 0.114 & 0 & 0.097468 \\
0.088 & 0.159 & 0.2 & 0.097658 \\
0.072 & 0.189 & 0.16 & 0.097721 \\
0.104 & 0.285 & 0.2 & 0.097911 \\
0.108 & 0.09 & 0.192 & 0.097911 \\
0.112 & 0.3 & 0.16 & 0.097911
\end{array}\right] .
$$

In this, ideal and nonideal solutions are as follows:

ideal: $0.264 \quad 0.3 \quad 0.2 \quad 0.097911$;

nonideal: $0 \begin{array}{llll}0.09 & 0 & 0\end{array}$. 
TABLE 2: Solution of study based on TOPSIS method.

\begin{tabular}{|c|c|c|c|}
\hline S. number & Substrate material & $C_{i}$ & Ranks \\
\hline $\mathrm{A}$ & $0.9\left(\mathrm{Zr}_{0.8} \mathrm{Sn}_{0.2}\right) \mathrm{TiO}_{4}+0.1 \mathrm{MgCO}_{3}$ & 0.399675 & 7 \\
\hline B & $\mathrm{La}_{0.4} \mathrm{Ba}_{0.6} \mathrm{Ti}_{0.6} \mathrm{Yb}_{0.4} \mathrm{O}_{3}$ & 0.40917 & 6 \\
\hline $\mathrm{C}$ & $0.58 \mathrm{ZnNb}_{2} \mathrm{O}_{6}-0.42 \mathrm{TiO}_{2}$ & 0.249265 & 10 \\
\hline $\mathrm{D}$ & $\mathrm{Ca}_{0.4}\left(\mathrm{~L}_{1 / 2} \mathrm{Nd}_{1 / 2}\right)_{0.6} \mathrm{TiO}_{3}$ & 0.729575 & 2 \\
\hline $\mathrm{E}$ & $\mathrm{Pb}_{0.6} \mathrm{Ca}_{0.4} \mathrm{ZrO}_{3}$ & 0.734938 & 1 \\
\hline $\mathrm{F}$ & $\mathrm{BaO}-\mathrm{PbO}-\mathrm{Nd}_{2} \mathrm{O}_{5}-\mathrm{TiO}_{2}$ & 0.475171 & 5 \\
\hline G & $\mathrm{Pb}_{0.45} \mathrm{Ca}_{0.55}\left(\mathrm{Fe}_{1 / 2} \mathrm{Nb}_{1 / 2}\right) \mathrm{O}_{3}$ & 0.501612 & 4 \\
\hline $\mathrm{H}$ & $\mathrm{Ba}_{4.2}\left(\mathrm{Sm}_{0.8} \mathrm{Nd}_{0.2}\right)_{9.2} \mathrm{Ti}_{18} \mathrm{O}_{54}$ & 0.338723 & 9 \\
\hline I & $\left(\mathrm{Ba}_{0.8} \mathrm{Sr}_{0.2}\right)_{4.2} \mathrm{Sm}_{9.2} \mathrm{Ti}_{18} \mathrm{O}_{54}$ & 0.52054 & 3 \\
\hline $\mathrm{J}$ & $\left(\mathrm{Ba}_{0.95} \mathrm{Ca}_{0.05}\right) \mathrm{O}-\mathrm{Sm}_{2} \mathrm{O}_{3}-4.5 \mathrm{TiO}_{2}$ & 0.341528 & 8 \\
\hline
\end{tabular}

From the weighted normalized matrix, the value of separation variables was found out to be

$$
\begin{array}{ll}
S_{1}^{*}=0.204887, & S_{1}{ }^{-}=0.307747 \\
S_{1}^{*}=0.186808, & S_{1}{ }^{-}=0.269745 \\
S_{1}^{*}=0.113565, & S_{1}{ }^{-}=0.342035 \\
S_{1}^{*}=0.339378, & S_{1}{ }^{-}=0.125794 \\
S_{1}^{*}=0.336173, & S_{1}{ }^{-}=0.121244 \\
S_{1}^{*}=0.225515, & S_{1}{ }^{-}=0.249083 \\
S_{1}^{*}=0.225355, & S_{1}{ }^{-}=0.223907 \\
S_{1}^{*}=0.160702, & S_{1}{ }^{-}=0.313732 \\
S_{1}^{*}=0.261725, & S_{1}{ }^{-}=0.24107 \\
S_{1}^{*}=0.157175, & S_{1}{ }^{-}=0.303036 .
\end{array}
$$

Now we can calculate the ideal solution from the following:

$$
C_{i}=\frac{S_{i}^{*}}{S_{i}^{*}+S_{i}^{-}} .
$$

So the ideal solutions are given in Table 2. The ranks are given based on their " $C$ " values. The material with highest $C$ value was given the best rank. So from these ranks we can say that, out of the selected materials, $\mathrm{Pb}_{0.6} \mathrm{Ca}_{0.4} \mathrm{ZrO}_{3}$ was found to be the best material for the substrate of microstrip patch antenna for WLAN application followed by $\mathrm{Ba}_{4.2}\left(\mathrm{Sm}_{0.8} \mathrm{Nd}_{0.2}\right)_{9.2} \mathrm{Ti}_{18} \mathrm{O}_{54}$ and $\left(\mathrm{Ba}_{0.95} \mathrm{Ca}_{0.05}\right) \mathrm{O}-\mathrm{Sm}_{2} \mathrm{O}_{3}-$ $4.5 \mathrm{TiO}_{2}$.

The outcome of this study is compared with the patent filed by Killen and his coinventors [14] and it is observed that using this material best performance of the antenna with miniaturized size can be obtained which is required for WLAN application. So this validates our study of dielectric substrate ceramic material for microstrip patch antenna.

\section{Conclusion}

This paper presented the material selection for the microstrip patch antenna substrate for WLAN applications using multiple attribute decision making (MADM) approach using technique for order preference by similarity to ideal solution (TOPSIS). It was observed that $\mathrm{Pb}_{0.6} \mathrm{Ca}_{0.4} \mathrm{ZrO}_{3}$ is the best material for the antenna substrate for WLAN applications followed by $\mathrm{Ba}_{4.2}\left(\mathrm{Sm}_{0.8} \mathrm{Nd}_{0.2}\right)_{9.2} \mathrm{Ti}_{18} \mathrm{O}_{54}$ and $\left(\mathrm{Ba}_{0.95} \mathrm{Ca}_{0.05}\right) \mathrm{O}$ $\mathrm{Sm}_{2} \mathrm{O}_{3}-4.5 \mathrm{TiO}_{2}$. This finding is also in agreement with the experimental results which justify the validity of the proposed study.

\section{Conflict of Interests}

The authors declare that there is no conflict of interests regarding the publication of this paper.

\section{References}

[1] S. C. Basaran and Y. E. Erdemli, "A dual-band split-ring monopole antenna for WLAN applications," Microwave and Optical Technology Letters, vol. 51, no. 11, pp. 2685-2688, 2009.

[2] C.-Y. Pan, C.-H. Huang, and T.-S. Horng, "A new printed Gshaped monopole antenna for dual-band WLAN applications," Microwave and Optical Technology Letters, vol. 45, no. 4, pp. 295-297, 2005.

[3] R. Zaker, C. Ghobadi, and J. Nourinia, "A modified microstripfed two-step tapered monopole antenna for UWB and WLAN applications," Progress in Electromagnetics Research, vol. 77, pp. 137-148, 2007.

[4] N. Gupta, "Material selection for thin-film solar cells using multiple attribute decision making approach," Materials and Design, vol. 32, no. 3, pp. 1667-1671, 2011.

[5] D. J. Kim, J. W. Hahn, G. P. Han, S. S. Lee, and T. G. Choy, "Effects of alkaline-earth-metal addition on the sinterability and microwave characteristics of $(\mathrm{Zr}, \mathrm{Sn}) \mathrm{TiO}_{4}$ dielectrics," Journal of the American Ceramic Society, vol. 83, no. 4, pp. 1010-1012, 2000.

[6] A. Feteira, R. Elsebrock, A. Dias, R. L. Moreira, M. T. Lanagan, and D. C. Sinclair, "Synthesis and characterisation of $\mathrm{La}_{0.4} \mathrm{Ba}_{0.6} \mathrm{Ti}_{0.6} \mathrm{RE}_{0.4} \mathrm{O}_{3}$ (where $\mathrm{RE}=\mathrm{Y}, \mathrm{Yb}$ ) ceramics," Journal of the European Ceramic Society, vol. 26, no. 10-11, pp. 1947-1951, 2006. 
[7] D.-W. Kim, D.-Y. Kim, and K. S. Hong, "Phase relations and microwave dielectric properties of $\mathrm{ZnNb}_{2} \mathrm{O}_{6}-\mathrm{TiO}_{2}$," Journal of Materials Research, vol. 15, no. 6, pp. 1331-1335, 2000.

[8] J. Kato, H. Kagata, and K. Nishimoto, "Dielectric properties of $(\mathrm{PbCa})(\mathrm{MeNb}) \mathrm{O}_{3}$ at microwave frequencies," Japanese Journal of Applied Physics. Part 1: Regular Papers and Short Notes and Review Papers, vol. 31, no. 9, pp. 3144-3147, 1992.

[9] K. Wakino, K. Minai, and H. Tamura, "Microwave characteristics of $(\mathrm{Zr}, \mathrm{Sn}) \mathrm{TiO}_{4}$ and $\mathrm{BaO}-\mathrm{Nd}_{2} \mathrm{O}_{3}-\mathrm{TiO}_{2}$ dielectric resonators," Journal of the American Ceramic Society, vol. 67, no. 4, pp. 278-281, 1984.

[10] E. S. Kim, J. S. Jeon, and K. H. Yoon, "Effect of sintering method on the microwave dielectric properties of $\left(\mathrm{Pb}_{0.45} \mathrm{Ca}_{0.55}\right)\left(\mathrm{Fe}_{0.5} \mathrm{Nb}_{0.5}\right) \mathrm{O}_{3}$ ceramics," Journal of the European Ceramic Society, vol. 23, no. 14, pp. 2583-2587, 2003.

[11] Y. Li and X. M. Chen, "Effects of sintering conditions on microstructures and microwave dielectric properties of $\mathrm{Ba}_{6-3 x}\left(\mathrm{Sm}_{1-y} \mathrm{Nd}_{y}\right)_{8+2 x} \mathrm{Ti}_{18} \mathrm{O}_{54}$ ceramics $(x=2 / 3)$," Journal of the European Ceramic Society, vol. 22, pp. 715-719, 2002.

[12] M. Imaeda, K. Ito, M. Mizuta, H. Ohsato, S. Nishigaki, and T. Okuda, "Microwave dielectric properties of $\mathrm{Ba}_{6-3 x} \mathrm{Sm}_{8+2 x} \mathrm{Ti}_{18} \mathrm{O}_{54}$ solid solutions with Sr substituted for Ba," Japanese Journal of Applied Physics, vol. 36, no. 9, pp. 6012-6015, 1997.

[13] A. G. Belous and O. V. Ovchar, "MW dielectrics with perovskitelike structure based on Sm-containing systems," Journal of the European Ceramic Society, vol. 19, no. 6-7, pp. 1119-1122, 1999.

[14] W. D. Killen, R. T Pike, and H. J. Delgado, "High efficiency slot fed microstrip antenna having an improved stub," US Patent, US 6791496 B1; 2004 , http://www.google.co.in/patents/US6791496. 

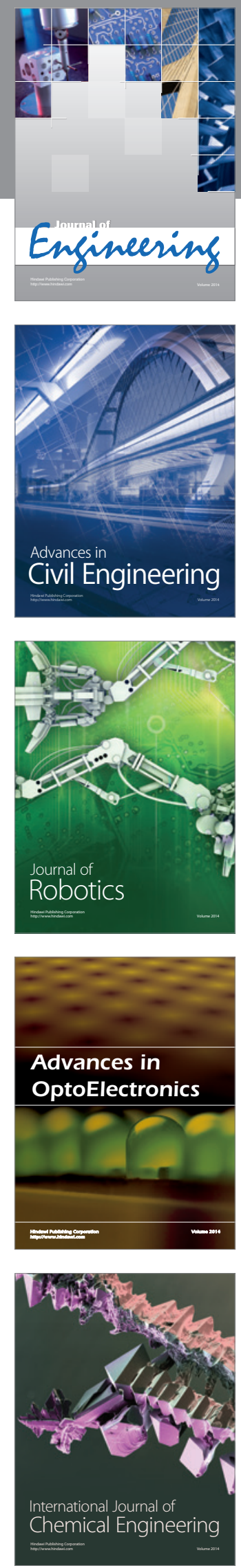

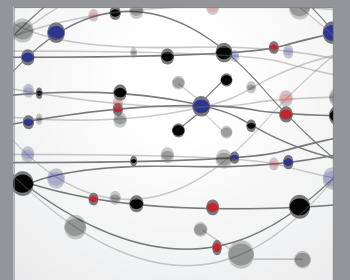

The Scientific World Journal
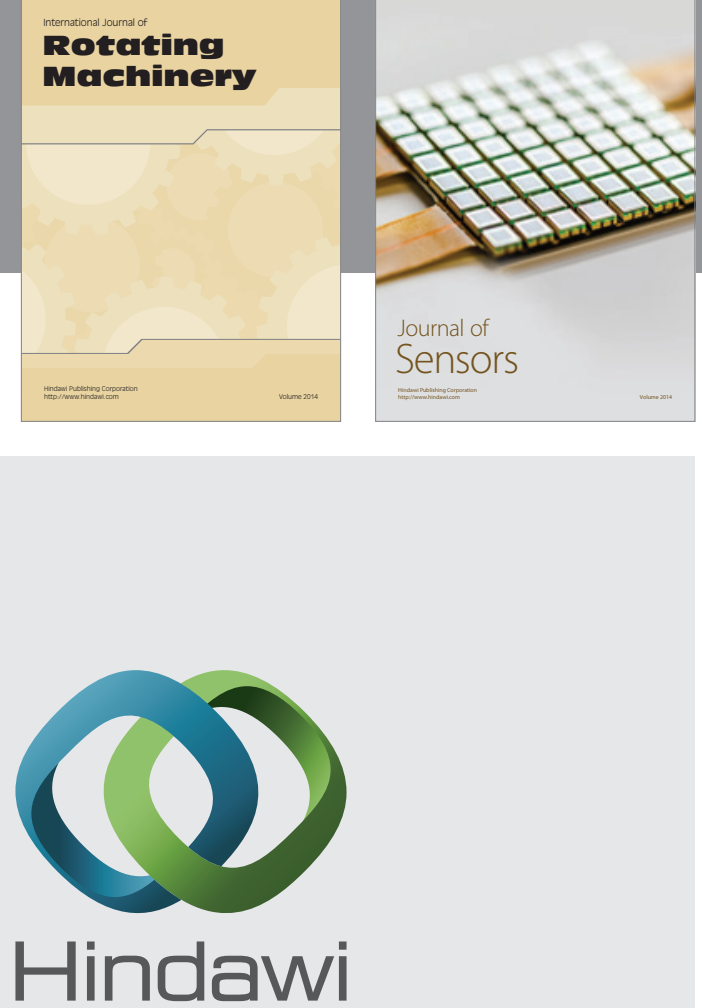

Submit your manuscripts at http://www.hindawi.com
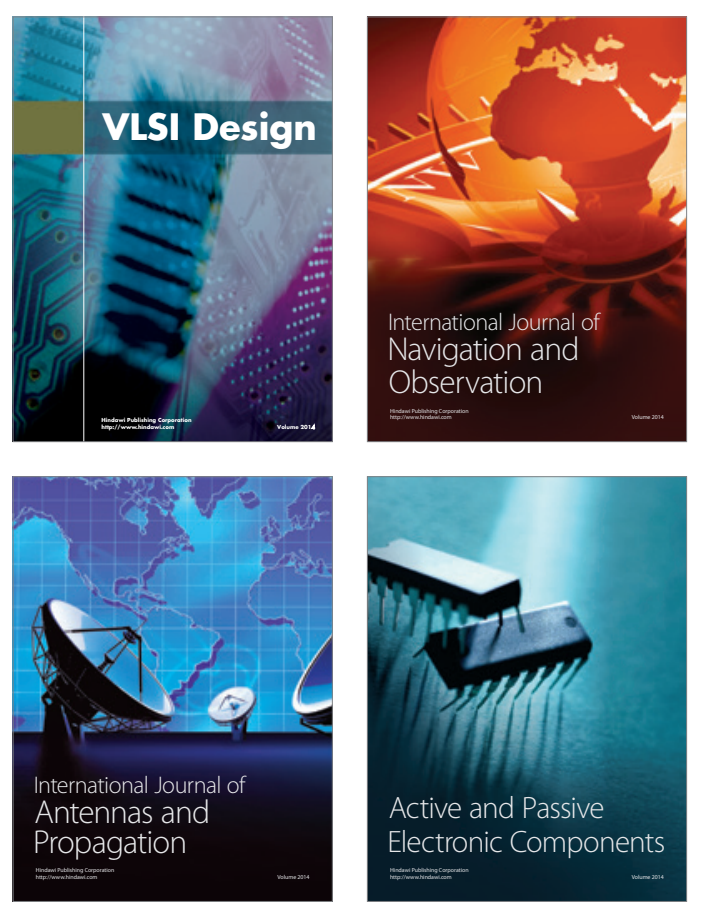
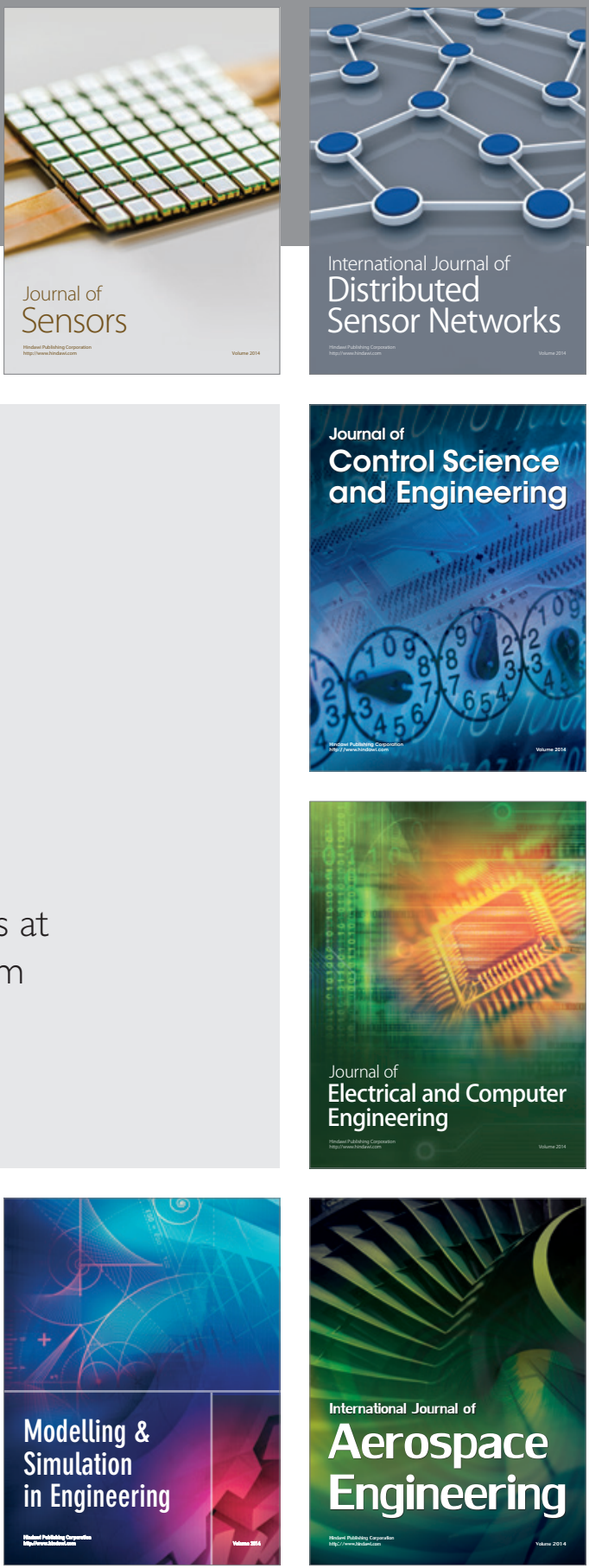

Journal of

Control Science

and Engineering
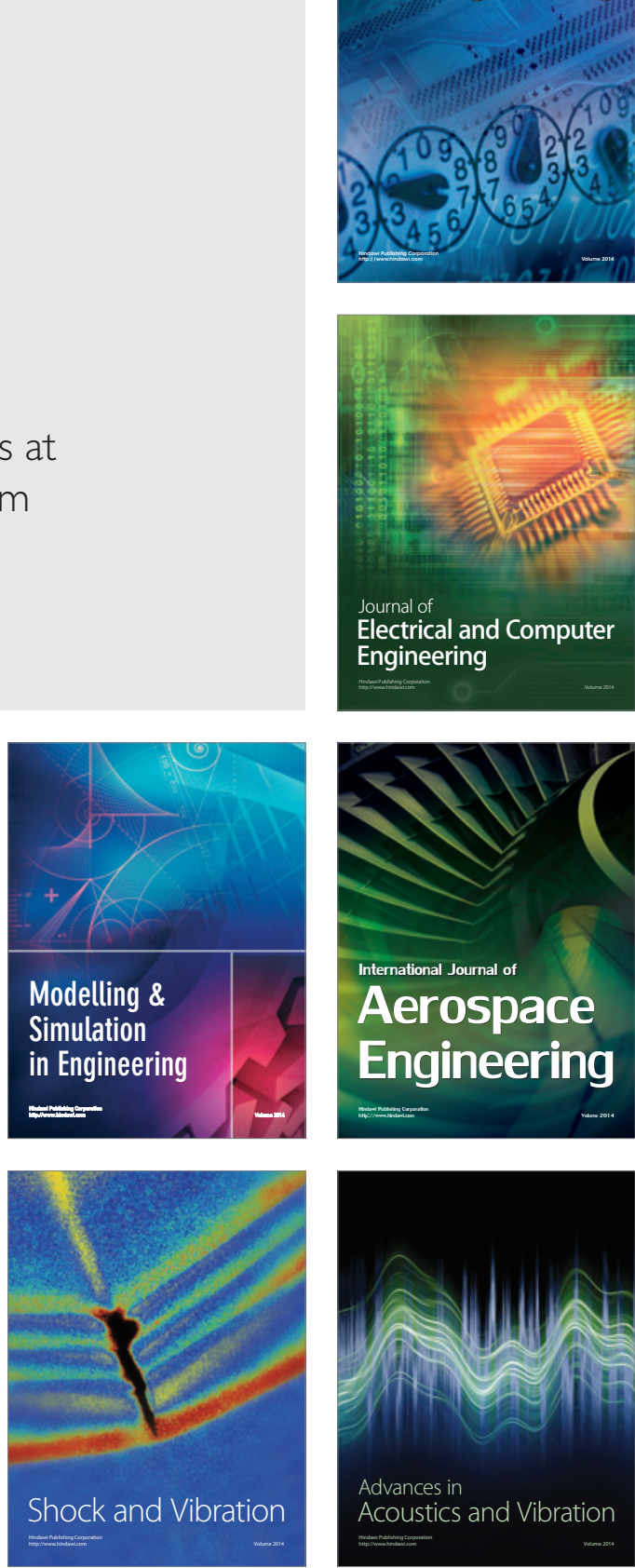